\title{
Inheritance of Resistance to Yellow Mosaic Virus Disease on Bambara Groundnut
}

\author{
Chitti Bharatkumar $^{1 *}$, R. Nandini ${ }^{2}$, Kailash Chandra $^{3}$ and K. Bhanuprakash ${ }^{4}$ \\ ${ }^{1}$ Department of Genetics and Plant Breeding, UAS, Dharwad, India \\ ${ }^{2}$ Department of Genetics and Plant Breeding, UAS, GKVK, Bengaluru, India \\ ${ }^{3}$ Department of Genetics and Plant Breeding, SKNAU, Jobner, India \\ ${ }^{4}$ ICAR-IIHR, Hessaraghatta Lake Post, Bengaluru, India \\ *Corresponding author
}

\section{A B S T R A C T}

Keywords

Yellow Mosaic

Virus Disease,

Bambara Groundnut

Article Info

Accepted:

20 October 2020

Available Online:

10 November 2020
Plant viral diseases inflict serious economic losses in major crops by reducing yield and compromising quality. The present study was conducted at K-block, University of Agricultural Sciences, Bengaluru. $\mathrm{M}_{2}$ generation was raised during summer season of the year 2014-15.The inheritance pattern of YMV disease was studied in $\mathrm{M}_{2}$ segregating populations of Bambara groundnut. In the $\mathrm{M}_{2}$ segregating populations of SB-42 and S165A studied, a good fit of 3: 1 (Susceptible: Tolerant) ratio was observed this indicates that single recessive gene controls tolerance to YMV disease in Bambara groundnut.

\section{Introduction}

Bambara groundnut (Vigna subterranea (L.) Verdc.), member of the family Fabaceae is a self-pollinating diploid annual legume crop with a chromosome number of $2 n=22$. It is an important food crop grown widely in semiarid Africa and it is closely related to cowpea (Vigna unguiculata) with which it shares its origin of genetic diversity. In Africa, Bambara groundnut is the third most important legume after groundnut and cowpea (Sellschope, 1962). Vigna subterranea is an extreme inbreeder; an autogamous crop with flower that are cleistogamous in nature
(Uguru and Agwatu, 2006), which gives rise to high percentage selfing since, the floral structure is perfect resulting in extreme inbreeding. For any effective selection programme genetic variation must exist. Radiation and other chemical mutagens have been used to induce variability in crop plants (Ahloowalia et al., 2004).

Viruses are one of the major constraints in pulse production among the plant pathogens affecting pulse production worldwide. Plant viral diseases inflict serious economic losses in major crops by reducing yield and compromising quality (Kang et al., 2005). 
Among several viral diseases of pulse crops, yellow mosaic virus causes major loss in the yield of the crop. In 1955 yellow mosaic disease was first identified in India and it occurs in a number of leguminous plants, i.e., mungbean, urdbean, cowpea, soybean, horse gram, lablab bean, french bean, moth bean and some other leguminous hosts; and some hosts of the family Malvaceae and Solanceae (Dhingra and Chenulu, 1985; Qazi et al., 2007). This disease was first reported in Bambara groundnut by Muniyappa and Veeresh, (1984) at UAS, GKVK, Bengaluru and subsequently by Smita Veeraghanti, (2012). The disease is characterized by faint yellow discoloration of young leaves and bright yellowing of older leaves on Voandzeia subterranea (Bambara groundnut) (caused by horse gram yellow mosaic virus). The chemical management of the vector is costly since numerous sprays of insecticides are required to control whitefly. Recently recurrent spraying has led to health danger and ecological influence. On the contrary, use of virus resistant varieties, if available, is the best approach to alleviate occurrence of Yellow mosaic virus disease in areas where the infection is a major constraint to production. Use of disease resistant crop varieties is regarded as an economical and durable method of controlling viral diseases.

\section{Materials and Methods}

The study was carried out at K-block, University of Agricultural Sciences, Bengaluru. $\mathbf{M}_{2}$ generation was raised during summer season of the year 2014-15. The experimental material for this study consist of two varieties of Bambara groundnut having good agronomic base belonging to different accessions viz., SB-42 (light brown, round shape and white hilum) and S165A (dark brownish, dark spotted surface and oval shape). These seeds were obtained from Directorate of Groundnut Research, Junagadh through National Bureau of Plant Genetic Resources.

Ethyl methane sulphonate (EMS) was used as a chemical mutagen to induce mutation in the seeds of Bambara groundnut varieties. EMS causes alkylation of guanine bases (G) leading to mispairing or mismatch pairing in the DNA of a treated organism as opposed to large deletions or rearrangements (Sharma and Sharma, 1986). Under these conditions, an alkylated $\mathrm{G}$ pairs with $\mathrm{T}$ in place of $\mathrm{C}$, causing a $\mathrm{G} / \mathrm{C}$ to $\mathrm{A} / \mathrm{T}$ transition in the backbone of the DNA (Henikoff and Comai, 2003). It can cause allelic mutations, small deletions (Schreck, 2002) and other chromosomal rearrangements (Barratt et al., 2001) depending on the position of the mutation.EMS was obtained from Spectrochem, Mumbai, India having a dosimetry/half-life period of 30 hours with a molecular weight of 124.16 and density of 1.20 .

Two hundred well matured healthy and uniform sized non-dormant seeds of each variety of Bambara groundnut were used for the chemical treatment. Five different concentrations of EMS 0.1, 0.2, 0.3, 0.4 and 0.5 per cent were used to treat the seeds. The solution of EMS was prepared corresponding to the required concentrations using double distilled water. The $\mathrm{pH}$ of aqueous solution was adjusted at 8.5 by using $0.2 \mathrm{M}$ solution of sodium tetra borate (Borax). The volume of solution prepared was about three times of volume of seeds. The seeds were pre-soaked in double distilled water for five hours at room temperature $\left(28 \pm 2^{\circ} \mathrm{C}\right)$ prior to treatment. After pre-soaking the excess of moisture in the seeds was then removed by filter paper. Seeds were then soaked in freshly prepared aqueous solution of different doses EMS for six hours at room temperature $(28 \pm$ $2^{\circ} \mathrm{C}$ ) with intermittent shaking after every hour. After the treatment, the seeds were 
washed thoroughly with double distilled water for eight to ten times and sown in the field along with control (untreated seeds). Presoaked seeds in only double distilled water for six hours were used as control.

\section{Screening M2 genotypes for YMV under natural field condition}

The $\mathrm{M}_{2}$ populations were subjected for disease screening under natural infection at 50 days after sowing (Selviet al., 2006). The $\mathrm{M}_{2}$ plants were classified based on per cent disease incidence of YMV for parents and individual plants of each $\mathrm{M}_{2}$ population as per procedure given by Selvi et al., (2006) and scales were depicted in the Table 1.

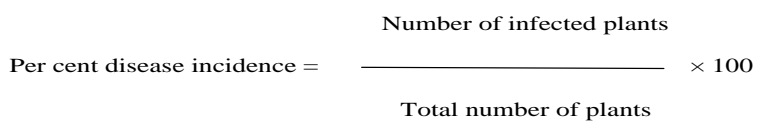

The inheritance pattern of YMV disease was studied in $\mathrm{M}_{2}$ segregating populations of Bambara groundnut. The disease resistance was classified into two groups, those with no apparent symptoms as resistant and those with visual expression of symptoms as susceptible. The reaction for the diseases was recorded as resistant and susceptible on all individual plants of $\mathrm{M}_{2}$ generation. The recorded observations were subjected to Chi-square test based on expected ratios. The goodness of fit between expected and observed segregation ratios were worked out. The Chi-square was calculated by using the following formula. Where, $\mathrm{O}=$ Observed frequency, $\mathrm{E}=$ Expected frequency. The significance of Chisquare value was tested by comparing the calculated Chi square value with table value at 5 Per cent and 1 Per cent level of significance at appropriate degrees of freedom ( $\mathrm{n}-1)$, where, $\mathrm{n}=$ number of classes of trait under consideration.

\section{Results and Discussion}

In the present study, the $\mathrm{M}_{2}$ populations of SB-42 and S-165A were screened during summer 2014 under natural field condition for YMV. All $\mathrm{M}_{2}$ populations were scored for YMV reaction under natural condition as per scale given by Selvi et al., (2006). In the $\mathrm{M}_{2}$ segregating populations of SB-42 and S-165A studied, a good fit of 3: 1 (Susceptible: Tolerant) ratio was observed and Table 2 and 3 suggests that single recessive gene controls tolerance to YMV disease in Bambara groundnut and these results are in agreement with the previous work of Shakoor et al., (1977), Anand Kumar et al., (2008) and Reddy (2009) (Fig. 1 and 2).

Table.1 YMV disease reaction scale

\begin{tabular}{|l|l|l|}
\hline Scale & Percent Disease Incidence & Disease reaction \\
\hline $\mathbf{0}$ & No infection & Highly resistant (HR) \\
\hline $\mathbf{1}$ & $1-5 \%$ mottling of leaves & Resistant (R) \\
\hline $\mathbf{3}$ & $5-10 \%$ mottling of leaves & Moderately resistant (MR) \\
\hline $\mathbf{5}$ & $10-25 \%$ mottling and yellow discoloration leaves & Moderately susceptible (MS) \\
\hline $\mathbf{7}$ & $\begin{array}{l}\text { 25-50\% mottling and yellow discoloration leaves } \\
\text { fruits }\end{array}$ & \begin{tabular}{l} 
Susceptible (S) \\
\hline $\mathbf{9}$
\end{tabular} \\
\hline
\end{tabular}


Table.2 Inheritance of YMV disease resistance in $\mathrm{M}_{2}$ populations of SB-42 variety

\begin{tabular}{|c|c|c|c|c|c|c|}
\hline \multirow{2}{*}{$\begin{array}{c}\text { Concentration } \\
\text { of EMS in per } \\
\text { cent }\end{array}$} & \multicolumn{2}{|c|}{$\begin{array}{c}\text { Number of plants in } \mathbf{M}_{2} \\
\text { population }\end{array}$} & \multirow[t]{2}{*}{$\begin{array}{c}\text { Total } \\
\text { Plants }\end{array}$} & \multirow[t]{2}{*}{$\begin{array}{c}\text { Expected } \\
\text { Ration }\end{array}$} & \multirow{2}{*}{$\begin{array}{c}\chi^{2} \\
\text { Calculated } \\
\text { value }(3: 1)\end{array}$} & \multirow{2}{*}{$\begin{array}{c}\chi^{2} \\
\text { Table } \\
\text { value }\end{array}$} \\
\hline & Tolerant & Susceptible & & & & \\
\hline 0.1 & 82 & 247 & 329 & $3: 1$ & 0.0010 & 3.841 \\
\hline 0.2 & 106 & 317 & 423 & $3: 1$ & 0.0008 & 3.841 \\
\hline 0.3 & 165 & 493 & 658 & $3: 1$ & 0.0020 & 3.841 \\
\hline 0.4 & 52 & 155 & 207 & $3: 1$ & 0.0016 & 3.841 \\
\hline 0.5 & 73 & 220 & 293 & $3: 1$ & 0.0011 & 3.841 \\
\hline
\end{tabular}

Table.3 Inheritance of YMV disease resistance in $\mathrm{M}_{2}$ populations of S-165A variety

\begin{tabular}{|c|c|c|c|c|c|c|}
\hline \multirow{2}{*}{$\begin{array}{c}\text { Concentration } \\
\text { of EMS in per } \\
\text { cent }\end{array}$} & \multicolumn{2}{|c|}{$\begin{array}{c}\text { Number of plants in } \mathbf{M}_{2} \\
\text { population }\end{array}$} & \multirow[t]{2}{*}{$\begin{array}{c}\text { Total } \\
\text { Plants }\end{array}$} & \multirow[t]{2}{*}{$\begin{array}{c}\text { Expected } \\
\text { Ration }\end{array}$} & \multirow{2}{*}{$\begin{array}{c}\chi^{2} \\
\text { Calculated } \\
\text { value }(3: 1)\end{array}$} & \multirow{2}{*}{$\begin{array}{c}\chi^{2} \\
\text { Table } \\
\text { value }\end{array}$} \\
\hline & Tolerant & Susceptible & & & & \\
\hline 0.1 & 80 & 241 & 321 & $3: 1$ & 0.0010 & 3.841 \\
\hline 0.2 & 56 & 170 & 226 & $3: 1$ & 0.0059 & 3.841 \\
\hline 0.3 & 140 & 421 & 561 & $3: 1$ & 0.0006 & 3.841 \\
\hline 0.4 & 55 & 160 & 215 & $3: 1$ & 0.0432 & 3.841 \\
\hline 0.5 & 39 & 121 & 160 & $3: 1$ & 0.0333 & 3.841 \\
\hline
\end{tabular}

Fig.1 Field view of bambara groundnut

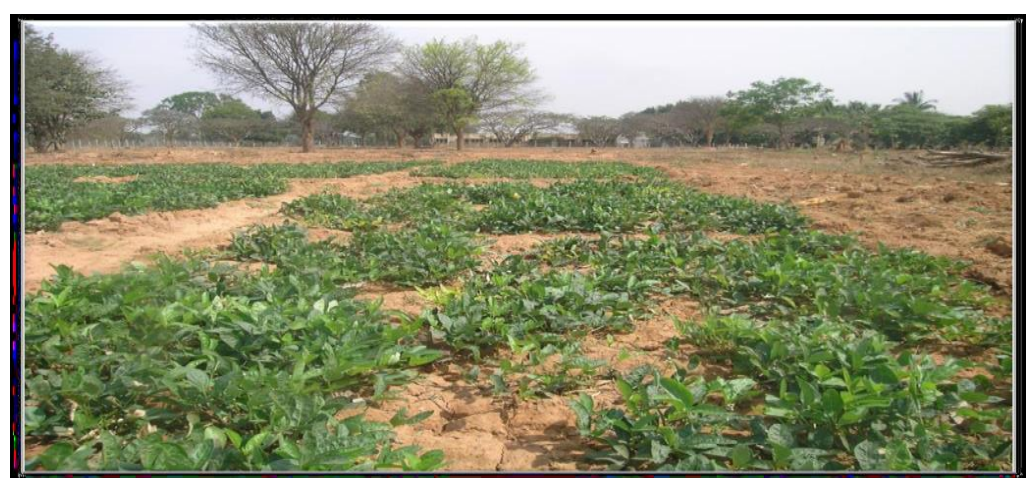

Fig. 2 YMV infected plants in M2 generation

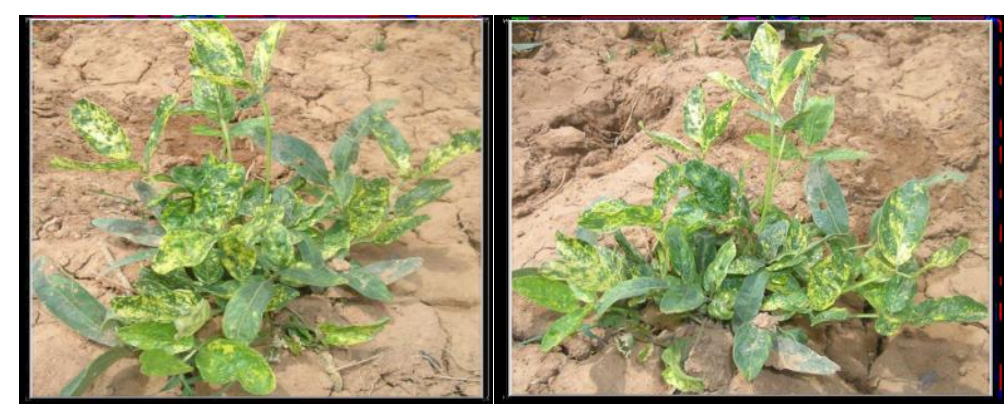


References

Sharma, S.K. and Sharma, B. 1986, Mutagen sensitivity and mutability in lentil. Theoretical and Applied Genetics, 71: 820-825.

Sellschope, J. P. F., 1962, Cowpea, (Vigna unguiculata (L.) Walp). Field Crop Abstr., 15:259-266.

Uguru, M.I. and Agwatu, U.K., 2006, Cytogenetic studies on bambara groundnut (Vigna subterranea (L.) Verdc.). J. Genet. Breed. 60: 10- 15.

Ahloowalia, B.S., Maluszynski, M. and Nichterlein, K., 2004, Global impact of mutationderived varieties. Euphytica.135:187-204.

Kang, B.C., Yeam, I. and Jahn, M.M., 2005, Genetics of plant virus resistance. Annu. Rev. Phytopathol., 43:581-621.

Dhingra, K.L. and Chenulu, V.V., 1985, Effect of yellow mosaic on yield and nodulation of soybean. Indian Phytopathol., 38: 248-251.

Muniyappa, V. and Veeresh, G.K. 1984. Plant virus diseases transmitted by whiteflies in Karnataka. Proc. Indian Acad. (Anim.). 93:397-406.

Smita Veeraghanti ,2012, Studies on genetic variability in M3 generation of Bambara groundnut (Vigna subterranea (L.) Verdc.) treated with gamma rays, M.Sc (Agri). Thesis, University of Agricultural Sciences, Bengaluru, India.

Henikoff, S. and Comai, L., 2003, Singlenucleotide mutations for plant functional genomics. Annu. Rev. Plant. Physiol. and Plant Mol. Biol. 54: 375-
40.

Schreck, S., 2002, The role of plastidia lphosphoglucomutase in carbon partitioning. PhD thesis. University of East Anglia UK.

Barratt, D.H.P., Barber, L., Kruger, N.J., Smith, A.M., Wang, T.L. and Martin, C. 2001, Multiple, distinct isoforms of sucrose synthase in pea. Plant. Physiol, 127:655-664.

Selvi, R., Muthiah, A. R., Manivannan, N., Raveendran, T. S., Manickama and Samiyappan, R., 2006, Tagging of RAPD marker resistance in mungbean (Vigna radiate (L.) Wilczek). Asian. J. Pl. Sci., 5 (2): 277- 280.

Shakoor, A., Haq, M.A. Sadiq, M.S and Sarwar, M., 1977, Induction of resistance to yellow mosaic virus in mung bean through induced mutation, Plant Dis, 214: 293-302.

Anand Kumar et al. (2008) Anand Kumar, Hepziba, S.J and Subramanian, M., 2008, Gamma ray and Ethyl methane sulphonate induced variability in blackgram (Vigna mungo (L.) Hepper). Annals of Agricultural Research 15:512-515.

Reddy, K.S., 2009, A new mutant for yellow mosaic virus resistance in mungbean (Vigna radiata L Wilczek) variety SML-668 by recurrent gamma-ray irradiation. In: QY Shu, eds., Induced Plant Mutation in the Genomics Era. Food and Agriculture Organization of the United Nations, Rome, pp. 361362.

\section{How to cite this article:}

Chitti Bharatkumar, R. Nandini, Kailash Chandra and Bhanuprakash, K. 2020. Inheritance of Resistance to Yellow Mosaic Virus Disease on Bambara Groundnut. Int.J.Curr.Microbiol.App.Sci. 9(11): 2529-2533. doi: https://doi.org/10.20546/ijcmas.2020.911.306 